\title{
Democracy in the Pacific Islands: Comparable Practices, Contested Meanings
} Jack Corbett*

*A slightly amended version of this article will appear in Dec 2015 issue of the journal Democratic Theory

\begin{abstract}
Shapiro identifies three traditions of democratic thought: aggregative, deliberative and minimalist. All three are apparent in the Pacific Islands despite most commentators and donors assuming that the meaning of democracy is fixed. The recent focus in development studies on institutions and their capacity to deliver pro-poor growth has generated a fourth tradition that revolves around the now pervasive governance concept. Rather than focusing on the general will of a sovereign people, this perspective is predominately concerned with the legitimate use of violence as a precursor to any development-orientated democratic state. Having reviewed the literature on democracy in the Pacific to parse out these four meanings, I conclude that paying greater attention to this ideational equivocality would extend discussions about the suitability and transferability of this type of regime.
\end{abstract}

Keywords: democracy, democratic theory, governance, Pacific Islands, Shapiro

Since decolonization came to the Pacific in the 1960s and 1970s there has been considerable debate about the most appropriate regime type for newly emergent nations. Colonialism disrupted previous forms of political organization and replaced them with a suite of institutions that are commonly labelled democratic. However, emergent democratic practices in the Pacific rarely followed the patterns found among similar regimes in Europe and North America. This divergence has largely been interpreted as the persistence and even reassertion of tradition in the face of all-encompassing modernization. Whether this is desirable and how it might be altered has attracted considerable commentary. The standard analytic move sets 
up an "insider-outsider" distinction that differentiates between the organic traditional order and the imposed democratic regime. In response, there have been concerted attempts to deconstruct the term tradition, with numerous scholars highlighting how practices given that label are in fact new and invented. Democracy, on the other hand, is tacitly assumed to have a fixed meaning. This article aims to unpack that assumption by parsing out four meanings of democracy in the Pacific region. In doing so it argues that paying greater attention to the current contest over meaning can enhance the old discussion about suitability and transferability.

The starting point for this analysis is Ian Shapiro's (2003) three traditions of democratic thought. The first two are wedded to the work of Jean-Jacques Rousseau and the belief that democracy is defined by the search for the general will. They emphasize that the general will is either established via the aggregation of preferences (i.e. elections) or constructed through sustained public deliberation. The third is more commonly associated with the work of Joseph Schumpeter and before him Niccolò Machiavelli who argued that the primary purpose of democracy is to minimize the domination of any one group over another. Despite much of the academic work on democratic politics in the Pacific Islands having virtually sidestepped questions about the meanings of democracy, the threads of all three traditions are apparent. Furthermore, I argue that over recent decades a fourth tradition has arisen around the now pervasive "governance" concept. The term itself has many of the hallmarks of an empty signifier - more useful for policy practice than theoretical discussion but I argue that it is underpinned by a fundamentally different logic to the three traditions outlined by Shapiro (more representative of Hobbes than Rousseau) as it advances a view of Pacific states as captured by pervasive societal interests. The general will, in this view, is not something to be identified or constructed, but rather is assumed to be contingent on a strong state capable of delivering development-orientated reforms. 
The aim of this four-part distinction is to highlight that while democracy has a history of stubborn persistence in the Pacific, there is less agreement about what the term means, its practices entail, and which version of it is ideal. So, instead of trying to explain why Pacific Island countries succeed or fail against Freedom House scores, I ask what democracy means in the Pacific region and how this meaning has changed over time. This exercise is premised on the anti-naturalist assumption that the meaning of concepts are historically contingent and context specific (Bevir and Kedar 2008). The four meanings of democracy identify are taken from the descriptions and prescriptions of academic commentators. Despite endogenous limitations, I employ this method because there are no widespread surveys of citizen attitudes about democracy in the Pacific from which to draw more empirically grounded conclusions. The review is not exhaustive - I have cited texts and authors to illustrate the core arguments, there are many more - and I do not have the space to provide a sociology of each of the four traditions (but see Van Fossen 2005; Larmour 2005). Certainly, I acknowledge that each has its own history and intellectual champions, and some have been more popular in certain periods, countries and institutions than others. The below review aims to provide a flavour of this diversity but I acknowledge that the analysis is necessarily parsimonious. The same caveat applies to the four traditions I identify. There are numerous ways that the literature can be differentiated analytically and we might reasonably expect that newer traditions will emerge. But for now the important point is that in contrast to indices like Freedom House, the meaning of democracy in the Pacific is not fixed - it diverges - with scholars and political actors drawing upon each of these different traditions to make sense of and enact their authority.

Before I review the literature on democracy in the Pacific Islands to flesh out this argument let me outline two caveats and a definition. Firstly, as outlined, much of the scholarship on democratic politics in the Pacific has taken on descriptive rather than 
theoretical forms and thus tends to implicitly gravitate towards either modernists or postcolonial theories. So, for the most part this review reinterprets existing scholarship to illustrate the different meanings of democracy that underpin this work. To that end, while I touch on debates about how and why representative democracy has been transferred, this is not my main focus (but, see Larmour 2005). Second, the literature on democratization provides important insights into the post-independence politics of the Pacific region. Again, I have reviewed this work elsewhere (see Corbett 2013a) and so will not rehash that analysis here, although there is some overlap at several points.

Echoing my assertion that democracy has multiple meanings, defining the Pacific is an inherently fraught undertaking. While I have intentionally chosen to treat the region as a single area, let me state from the outset that I acknowledge that it is a highly diverse construct with ambiguous geographical and ideological boundaries. I employ it here to describe fourteen independent and self-governing political entities: Papua New Guinea, Solomon Islands, Vanuatu and Fiji in Melanesia, Tonga, Samoa, Cook Islands, Tuvalu and Niue in Polynesia, and Marshall Islands, Palau, Federated States of Micronesia (FSM), Kiribati and Nauru in Micronesia. Again, there is some ambiguity about what self-governing means at the beginning of the twenty-first century. Bougainville and New Caledonia, for example, are scheduled to hold referendums on their future political status this decade. Elsewhere, territories of France, the United States and New Zealand have legislatures and hold elections, despite not being considered sovereign states. The most common institutional setup is a Westminster-inspired parliamentary system, but the Pacific also has a presidential system and hybrids of the two. The size of legislatures also varies considerably (FSM's congress has 14 members, while Papua New Guinea's parliament has 109). Fiji’s pre-2006 parliament and Palau's congress are bicameral. Many others have constitutionally mandated councils reserved for chiefs and traditional leaders - until recently the majority of seats in Tonga's 
legislative assembly were reserved for nobles—while assorted types of state, provincial, and local government assemblies add to this somewhat eclectic mix of institutional architecture. Furthermore, reflecting the assortment of political institutions in the Pacific Islands, electoral systems are similarly varied (Fraenkel 2010; Levine 2009).

\section{Democracy as the Aggregation of Preferences}

The essence of the aggregative tradition of democracy, Shapiro (2003) argues, is competition for the majority vote. From this perspective institutional design and electoral systems in particular are the core features of democratic government, and as a result most political scientists working in this tradition in the Pacific have focused their efforts on documenting election results and describing campaigns. In Papua New Guinea every election since 1964 has been the subject to a comprehensive academic study (all but the 2002 election has since been published as an edited book, see May et al 2011: vii) but the practice is common elsewhere, too. The University of Hawaii's Norman Mellor pioneered this type of "election study" in Fiji (Meller and Anthony 1968) and Micronesia (Meller 1969) in the 1960s. Fiji has since been subject to several election studies (Lal 2000; Firth and Fraenkel 2007). In the 1990s, Howard Van Trease at the University of the South Pacific edited a number of books that drew heavily on elections, including on Vanuatu (Van Trease 1995) and Kiribati (1993). In recent decades, this work has tapered off outside Papua New Guinea and Fiji but both regional and international organisations - namely the Pacific Islands Forum Secretariat and the Commonwealth Secretariat - continue to conduct and publish election observation reports. Combined, this body of scholarship, and the edited collections in particular, represent a significant proportion of the academic commentary and analysis of democracy in the Pacific Islands. 
Election studies tend to revolve around several debates important to the aggregative tradition, with the role of political parties and the integrity of results the two most prominent concerns. Let me start with political parties. Framers of Pacific constitutions, whether adopting a presidential, parliamentary or hybrid design, generally assumed that political parties would form and shape parliamentary politics. In the period immediately following decolonization this prediction appeared accurate but since then election studies have consistently observed that parties have tended to fracture, with their success dependent on the profile of their leader rather than the policy platform they stand for (for discussion see Rich et al 2008). Fiji is the main exception to this trend as political parties are largely split along ethnic lines - Indigenous-Fijian versus Indo-Fijian - thus reinforcing the more general rule. Following the old view that democracy without parties is unthinkable (Schattschneider 1942), donors in particular have sought to redress this deficit by running training programs for party officials. The assumption, echoing Max Weber's (1978) view of political professionalization being driven by the bureaucratization of party organizations, is that the absence of parties is underpinned by the lack of institutional knowledge and technical expertise required to manage them properly. The alternate initiative, most commonly funded by the United Nations Development Program, is voter education programs designed to create an active and enlightened citizenry capable of exercising their democratic rights and responsibilities (i.e. to stop citizens voting for family members). The assumption here follows from Seymour Martin Lipset's (1959) belief that successful democracy is contingent on the presence of an educated middle class.

One consequence of these practices has been executive instability as precarious parliamentary coalitions in Westminster systems have tended to be regularly overturned by votes-of-no-confidence; Fiji aside, Pacific Island countries have had the opposite problem to that outlined in Huntingdon's "two-turnover test" (concurrent changes of government signify 
democratic consolidation). Electoral and constitutional engineering has been the main method employed by those working in the aggregative tradition to restore stability. In Papua New Guinea the Organic Law on the Integrity of Political Parties and Candidates (OLIPPAC) restricted MPs from crossing the floor once elected. This legislation was ultimately found to be unconstitutional but similar attempts have been undertaken or considered elsewhere (see Paeniu 2012), although their success is often mixed.

While the absence of parties has been the primary concern of scholars and policy makers in recent years, the deeply divisive nature of post-independence politics in countries like Fiji has also brought the analysis of electoral systems to the fore. Most commonly, this debate has centred on the work of Arend Lijphart and Donald Horowitz (for discussion see Reilly 2001; 2006, Fraenkel 2004a; Fraenkel et al 2008). Horowitz was influential in shaping the provisions of Fiji's now abrogated 1997 constitution that included a shift from first-pastthe-post (FPP) to the alternative vote (Lal 1998; Larmour 2005: 84). A similar shift occurred in PNG where scholars continue to debate the merits of limited preferential voting with some arguing that it has decreased the violence apparent at the 2002 election in particular (e.g. Standish 2006) while others argue that it has led to an increase in "money-politics".

This latter observation segues neatly into the second predominant concern among scholars working in the aggregative tradition: the integrity of elections. We can think of the scholarship on the integrity of elections as having a number of faces. The first is procedural and is concerned with the relative benign but important aspects of electoral administration. Most commonly, election studies observe consistent irregularities in the electoral roll, for example, and cite the incapacity of electoral commissions to meet logistical needs. At the more threatening end of the scale, election studies observe coercion (including via sorcery and witchcraft) and violence around elections, especially in Papua New Guinea but not 
exclusively so. In this view, women and youths in particular are intimidated into voting for specific candidates, and thus undermine the notion of "one-vote-one-value".

Most commonly, however, scholars working in the aggragative tradition have recently been concerned by the prevelence of practices commonly described as "money politics", "vote buying" and "bribery" at elections. Gifting and largesse are among the most contentious electoral issues in the Pacific Islands, in part because there are numerous ways these practices are interpreted (for review see Larmour 2012). The accepted wisdom is that these charatersitics of Pacific electioneering are on the rise.

In sum, scholars working in the aggregative tradition tend to give the Pacific a mixed report card. They applaud the frequency of elections and note that by and large the Pacific has not been home to long lasting authoritarian regimes. Even Fiji, with its history of coups, has tended to find a way of reinstating democracy. On the other hand, these same scholars

criticize the presence of practices that pevert the aggregation of the general will, including the absence of political parties, electoral maladministration and money politcs. From this perspective, Pacific Island democracy requires strengthening.

\section{Democracy as Deliberation and Consensus}

In contrast to the aggregative approach, the assumption for those operating in a deliberative tradition is that the general will is not out there waiting to be calculated; it must be manufactured via sustained public debate and discussion. The idea is that when making policy decisions democratic citizens need to move beyond narrow self interests and consider what constitutes the common good for society. While different to the aggregative approach, this tradition is also typically antipatheitc to the types of largesse described above but on different grounds; modern money politics is either a perversion of traditional forms of exchange, or the presence of moneyed interests in the public sphere corrupts rational debate. 
In the first view, democracy in the Pacific is seen to have disrupted, displaced and spoiled previous systems of pre-colonial deliberation that were more legitimate than transferred institutions. In the second, mechanisms like elections sharpen cleavages, be they ethnic or geographic, and thus work against unity and prosperity.

A belief that the values and principles of "modern" state-based institutions are at odds with "traditional" or "cultural" forms of political authority has historically been the main rubric through which commentators but also Pacific leaders have conceptualised the relationship between the state and society in the region since independence. The most influential anthropological taxonomy of political authority is Marshall Sahlins' (1963) distinction between the achieved leadership of the Melanesian "Big Man" and the ascribed leadership of the Polynesian “Chief." Specifically, Sahlins' characterised Polynesian chieftancy as the more evolved form of leadership. The implicit standard in this view is modernisation theory with its emphasis on enlightenment rationality. "Culture", from this perspective, is a catchall term used to describe features of Pacific society, including collective land tenure and kin-based reciprocity. I will discuss how supporters of modernization theory see the persistence of traditional norms and values, including ideas about rank and hierarchy, as corrupting ideals like "one-vote, one-value" in detail below. For now, I want to focus on those scholars who see modern democratic politics as perverting the types of pre-colonial rule Sahlins' described on the grounds that they favored deliberation and consensus over competition.

Writing about institutional transfer, Larmour (2005) notes that in the Pacific Westminster is often seen as a negative symbol of introduced government that stands in opposition to traditional forms of authority. In countries like Tonga and Fiji where democratic transition faced opposition, Stephanie Lawson (1996) finds some elites refer to the idea of representative government in a Westminster mould as "democracy". Similarly, in 
his research on local conceptions of politics in northern Vanuatu, Michael Morgan (2003, p. 229) finds that negative aspects of politik, particularly the divisiveness encouraged by the democratic state, are juxtaposed with ideas about kustom, including the idealization of consensus, community, and the natural order of control by big men. In this view, as Larmour (2005) highlights, democracy in the Pacific is cast as a "foreign flower"; unable to take root and therefore unsuitable for Pacific soil.

Scholars working in the postcolonial tradition have often espoused a similar view. Phrases like the Pacific, Melanesian or Micronesia "Way" - terms that usually refer to shared ideas about solidarity and reciprocity, the fostering and maintenance of kinship networks and relationships, attachment to land and the ocean, respect, dignity, consultation, and shared leadership (see Crocombe 1976; for discussion see Lawson 2010) —are often employed in opposition to democracy as a form of foreign intervention. The emphasis here is on the ways colonizers (mis)treated indigenous peoples, the hypocrisy of departing colonial powers who practised dictatorship but made independence contingent on democratization (Ravuvu 1991), and the subsequent neo-imperialism of post-colonial interventions to support democracy, be they in the form of aid or military assistance (e.g. Fry 1997; Fry and Kabutaulaka 2008). In such cases the ideals of democracy are generally not subject to sustained criticism - most maintain that indigenous values and beliefs are equivalent if not better than those espoused by Europeans or Westerners, and thus tacitly presume that a form of egalitarianism is a normative good (e.g. Hau'ofa 1993) - but instead argue that the processes by which they have been transferred can explain many of the subsequent problems that have arisen with democratic practice. In which case, this view differs from the above notion that traditional leadership and democracy are antithetical. The two overlap, however, in that terms like the Melanesian Way seek to denote a positive identity and in doing so draw on a particular view of the pre-colonial past (for discussion see Lawson 2013: 15). 
Attempts to enshrine a role for traditional leadership is apparent in a number of constitutions around the Pacific region (for discussion see Larmour 2005a: 67-86). Constitutionally mandated councils of traditional leaders have limited formal powers but nevertheless can retain a prominent public voice on matters relating to land and cultural heritage. Aside from divine right, in such cases, "the argument against Westminster becomes one for decentralization or federalism in order that introduced systems can more closely approximate the scale of indigenous ones" (Larmour 2005: 232). Certainly, across the region there exists a strong appetite for reform, among even the smallest countries (see for example Panapa and Fraenkel 2008 on Tuvalu).

The goal of consensus, understanding and reconciliation are also at the heart of recent attempts to employ a Talanoa process of dialogue and discussion as both a research methodology and a conflict resolution mechanism in the Pacific. East-West Centre academic and one-time Tongan parliamentarian Sitiveni Halapua facilitated this process in Fiji after the 2000 coup (and later in Solomon Islands and Tonga). He conceptualises Talanoa as "storytelling without concealment", and as such it revolves around learning through sharing with the aim of strengthening interpersonal bonds, enhancing respect for differences and forging broad consensus (Halapua 2002; 2013). For Halapua, democracy does not have to be a "foreign flower" if it is practised in a way that is consistent with the principles of Talanoa.

The emphasis on consensus is also a point of some contention in the literature on politics in small states. Political theorists have long argued that when it comes to democratic politics, "small is beautiful" (see, most famously, Dahl and Tufte 1973). Largely, advocates of this perspective hark back to antiquity and extol the democratic benefits of face-to-face society. Echoing this, Teresia Teaiwa (2005: 271) wonders how Pacific Islanders can "hold grudges against people whom they cannot avoid, people they are bound to run into at the supermarket, the market or the street, people whom they are often bound by blood and 
history?" The alternate view, put most succinctly by Jeffrey Richards (1982: 160), is that if "friendships run deeper then so do enmities". This type of equivocality is also apparent in the literature on politics and religion. Pacific Island countries are overwhelmingly Christian. From a deliebrative view, churches are often portrayed as also seeking to promote concensus even to the point of outright withdrawal from public life. In contrast, politics in the Pacific can also be overtly religious with campaigns and speeches heavily infused with religious parochialism (see Corbett 2013b).

In contrast to these somewhat nostalgic renderings of a consensual pre-colonial Pacific society, some scholars have critiqued they way "tradition" is employed to support ostensibly undemocratic practices in the Pacific. Lawson (1996), for example, notes that such views are comparable to sentiment expressed in Burkean political thought. This view can help us understand why in some of the more hierarchical Pacific societies, Tonga for example, successive generations have chosen to migrate rather than live under a monarchical regime in which their life choices are dictated by the accident of birth. Similarly, Jon Fraenkel's (2004b) analysis of the political tensions that consumed Solomon Islands during the late 1990 s and early 2000 s points to the way custom was manipulated to serve the interests and legitimise the actions of warring militias and a few fading politicians. While famous for extolling the virtues of the Melanesian Way, Papua New Guinean, lawyer, philosopher and former MP, Bernard Narakobi's (1983) book Life and Leadership in Melanesia is critical of the way contemporary leaders abuse reciprocal traditions to consolidate their hold on power, an interpretation often associated with ideas like "Melanesian socialism". Similarly, in his biography of the inaugural president of FSM, Tosiwo Nakayama, David Hanlon (2014) acknowledges that a Gramscian reading of his life might portray him as tacitly complicit in the colonial project, and thus wilfully manipulating the decolonisation process to serve his and other political leaders interests (although he 
rejects this reading himself). Donors and international agencies like Transparency International also regularly see the manipulation of culture as a root cause of corruption.

Finally, to come full circle and return to modernization theory as discussed at the outset of this section, the other critique of values like deliberation and consensus emanates from the development enterprise itself. In this view, the emphasis on constructing a shared understanding of the common good amounts to fiddling while Rome burns. Material interests, advocates argue, are more important than lofty ideals. Both Marxists but also market-orientated liberals common to donor agencies tend to share this "doomsday" view (Callick 1993), which characterizes Pacific Island countries as beset by numerous social and political problems that necessitate immediate action and reform. There is a hint of Carl Schmitt (2007) in this reading; democracy offers only temporary or occasional answers to complex but pressing problems. Channelling this, development agencies are increasingly turning towards leaders and leadership as solutions to this malaise (e.g. Leftwich 2010). Leadership, from this perspective, is defined as action orientated - bold and decisive - with values like compromise, conciliation and consensus sidelined in the interests of progress and material advancement.

\section{Democracy as the Minimization of Domination}

The third tradition that Shapiro identifies defines the common good in a democracy as "that which those with an interest in avoiding domination share" and so pluralism and competition are the essence of sound government. There are two ways of thinking about the minimization of domination view of democracy in the Pacific: descriptive and normative. Let me tackle the latter first. Almost nobody supports this view of democracy on normative grounds.

Democracy and development are ubiquitous and co-dependent discourses in the Pacific with the extent to which the former is in crisis measured by the success of the latter (for further 
discussion see Corbett 2013a). In contrast, the minimization of domination view sees the maintenance of democracy as a normative good in its own right (although the assumption is that by providing a safe guard against authoritarianism, democracy will serve the material interests of the many in the long run; it's a thin rather than thick view of the common good). So, this section is necessarily brief as it is concerned with exceptions rather than the established traditions of the field.

There are three main views. The first is captured in growing donor interest in "political settlements" as compromised but necessary features of public life (e.g. Laws 2012), especially in countries like Solomon Islands that have experienced recent conflict. This view of democracy has older roots, particularly in the Western Melanesian countries of PNG, Solomon Islands and Vanuatu, all of which have been described as hyperfactionalized due to the diversity of cultures and languages. The claim is that the nature of the political settlement in these settings - factionalized, weak political parties, high levels of patronage-based money politics - guards against the capture of state institutions by one group (Reilly 2008). While distasteful to many, in this interpretation the perpetual side-switching or "grass hopping" of MPs in these countries actually helps us understand why democracy persists, despite the practical challenge it poses to executive governments; institutional uncertainty provides actors with an incentive to remain committed to the process. This view is also bolstered by the argument that most "Pacific countries have a relatively free press, more or less independent judiciaries and, despite some glaring irregularities, few examples of overtly rigged elections" (Fraenkel 2005: 263).

The second can be found in the corruption literature (e.g. Walton 2013) and the argument that where the state is weak or absent, largesse can be highly functional with elections functioning as a grandiose and ritualized process of wealth redistribution whereby the people exercise their authority over elites seeking legitimacy for their continued status 
(see also Corbett 2015). While often offensive to liberal sensibilities, the argument is that this form of largesse can contribute to the maintenance of democracy as elites are forced to part with substantial amounts of money during and after election campaigns, the net effect of which is a redistribution of wealth that mitigates poverty and social exclusion. Rather than buying votes, politicians are coaxed into parting with their wealth not only by their sense of duty and obligation to their family and kin, but also by the promise of prestige and status that a position in parliament symbolizes.

The third is the classic institutional view of competition that has its roots in the Federalist Papers. Concerned with the possible domination of Chuuk State, Micronesian constitution writers designed a federal system that limited the formal powers of the national government. The trade-offs contained in the 1975 Micronesian constitution has led some commentators to describe national government in FSM as subject to "all checks and no balances" (Underwood 2006). For many this has resulted in frustrating impotence but subsequent constitutional conventions have elected not to change the original document, and despite the spectre of further separatism, the federation holds together. This state of affairs could be interpreted as an argument for the presence of constitutionally mandated factions that minimize domination.

In contrast, most Pacific Island countries operate Westminster-inspired parliamentary systems that have none of these veto points - federalism, bicameralism or presidentialism and so in theory they should entrench executive domination (Fiji's pre-1987 constitution is an exception as it provided for a bicameral legislature). Empirical support for this view of majoritarian government, classically associated with Lijphart (1999), comes in the form of scholarship that describes populist leaders, especially around independence, as treating their countries like personal fiefdoms due to their ability to control nearly all aspects of political and social life. Crocombe (2008) identifies Nauru's Hammer DeRoburt, Cook Islands' Albert 
Henry and Marhsall Islands' Amata Kabua as examples of this trend. In such circumstances, the argument for more democracy is couched in terms of its ability to limit this type of domination. Similarly, Akilisi Pohiva's decades of long struggle for democratic reform in monarchical Tonga has been underpinned by analogous concerns.

Normative questions aside, the minimization of domination view of democracy has been attributed with significant descriptive power in the Pacific. Indeed, we might conclude that it is the predominant description of contemporary parliamentary politics in which the executive is perpetually unstable, parties are weak or absent, MPs constantly cross the floor and the allocation of resources is determined by overt "pork barrelling" (see most famously Steeves 1996). Certainly, all three alternative rationales for democracy in the Pacific discussed in this article would share elements of this descriptive characterization. Where they differ, however, is in the normative desirability of these trends, with most considering them eminently undesirable and therefore in need of urgent reform. The status quo, many maintain, is untenable in the long term and thus threatens the existence of stable government. This view is supported by the assertion that civil society is weak across the region and therefore requires strengthening (for review see Haley 2008). Journalists and reporters are often quick to advance this view of democracy. They point to the unwillingness of political leaders to accept public criticism to support this view (see Field, 2010; Moala 2002). Similarly, scholars working on gender note that the region has one of the lowest levels of women's parliamentary representation in the world (e.g. Baker 2014). From this standpoint, minimalist democracy means patriarchal democracy. Churches are often implicated in this view. Echoing the precepts of the aggregative tradition, the solution for gender scholars tends to involve a combination of positive discrimination measures (reserve seats for women), candidate training, and vote education. 


\section{Democracy as Institutional Governance}

The above discussion considers domination as a nesecary but dangerous feature of political life, with democracy primarily designed to minimize its excess by ensuring "ambition is made to counteract ambition", to borrow Madison's famous phrase. Conversly, in recent decades a view of government in the Pacific has emerged that views domination in a fundementally different light. This view is not entirely new - as outlined, it draws on older European thinkers, like Hobbes, and also resonates with cheifly ideas about leaders being trained in the art of government - but it has been given a distinctly contemporary twist by development theory. This thinking primarily arose from the (re)discovery of institutions by political scientists and economists in the mid-late 1980s. From this, the so called "good governance" agenda mixed aspects of classic Weberian renderings of the ideal bureacracy with new public management doctrine. As a result, whereas for much of the previous two decades development studies scholars had debated whether economic advancement was best achieved by fostering capital growth or meeting basic needs, both ideas became contingent on getting the mix of government institutions right. There is an established litreature on this move and so I will not canvass it at length here (but see Carothers and De Gramont 2013 for a review), the important point is that it is now the most prevalent body of work on democratic politics in the Pacific (especially given the post-2001 focus on terrorism) despite the fact that it has an ambiguous view of the normative desireability of this form of regime.

The main reason why this tradition of thought has a varied view of democracy is that despite its many guises and machinations it sees the legitimacy of the regime as resting on the monopoly of the legitmate use of violence rather than the free will of soverign people. In this view, the Pacific is home to a series of weak states and strong societies, to borrow from Migdal (1988), and the best way to deliver development is to strengthen the former. Democracy features in some versions of this story - Huntington (1968) advocated a 
sequential argument in which state capacity is a precursor for democratisation - but largley this view emphasises the importance of law and order, regulation designed to curb the excess of leaders, and an impartial and professional civil service (for review see Norris 2012). In particular, the type of executive instability, outlined above, is especially problematic as it distrupts public policy formation and implementation, and encourages patronage-based politics.

As a result, much of the debate in this litreature has revolved around revisiting older discussions about fragmentation, both as it relates to fluid coalition groupings within parliament and separatist or breakaway movements (e.g. Bougainville and West Papua) outside of it, especially in Western Melanesia. This ties in neatly with the electoral engineering discussion, outlined above, and the emphasis of some donors on strengthening political parties. In both cases, the aim is to create an executive that is as detached as possible from society - not bound by petty localisms or patronage networks - that can make decisions for the good of the country as a whole. These elites are then held accountable by leadership codes and oversight regimes like ombudsman and anti-corruption commissions. Indeed, work on corruption in the Pacific has grown as a result of this governance focus (Larmour 2012). The 2006 coup in Fiji was justified by its leader, Commadore Frank Bainimarama, on the grounds that the current crop of democratically elected parliamentarians were too corrupt to hold power; an avowedly good governance coup. Perhaps unsurprisingly, his attempts to clean up corruption have had mixed success (Larmour 2012). Nevertheless, a nostaligic view of benign authoritarianism echoes across the region as people become increasingly cynical about the actions of politicians and lose hope in the messy, unstable and unpredictable nature of contemporay democratic politics.

The strong institutions view of democracy in the Pacific has also been used to justify foreign interventions. "New Interventionism" is the term used by international relations 
scholars to describe Australia's $21^{\text {st }}$ century role in the Pacific generally, and Solomon Islands in particular (e.g. Fry and Kabutaulaka 2008). In such circumstances the inability of the state to secure a monopoly on the legitimate use of violence was a catalyst for soldiers and police, and later development professionals, to "rebuild" Solomon Islands democracy. The Regional Assistance Mission to Solomon Islands had several pillars, including law and order. It has attracted sustained critique from scholars working in the post-colonial tradition. Others concerned with its paternalistic undertones have sought to reconceptualise its activities as contributing to a "hybrid" political order in which Weberian institutions operate in parallel with more traditional forms of rule (e.g. Hameiri 2009; Allen and Dinnen 2010).

Finally, the size of Pacific democracies features heavily in discussions of institutional governance. In this view, the (in)capacity of Pacific states is tied to their small size, which imposes limits on their economic growth potential (Bertram and Watters 1985; Connell

2013). Echoing the tension between Weberian and new public management thinking in public administration, in promoting good governance via public sector reform throughout the 1990s, economists have been less concerned with extending the strength and reach of state-based institutions but rather have focused on making them more effective and efficient. In general, countries with the smallest population sizes are said to face the severest challenges. On the other hand, comparative politics scholars identify a strong correlation between small size and democratisation (for review see Veenendaal and Corbett 2015) and the Pacific is no exception. In this view, small size and even the absence of economic development underpins the persistence of democratic government in the Pacific.

\section{Conclusion: Democracy as Contested Traditions}

The standard theme in Pacific Studies revolves around the difference between "insider" and "outsider" perspectives, and who is and is not entitled to speak about the region. Following 
this, democracy is typically characterized as foreign and imposed whereas pre-colonial forms of political organization are considered local and organic. Since the 1980 s there has been a considerable body of scholarship that focuses on the invented nature of so-called traditional practices. Rather than a static and timeless past, historians and anthropologists in particular have shown how political organisation have always been contested. In doing so they have highlighted the multiple meanings of tradition in the contemporary Pacific. In this article I have sought to make an analogous move by showing that democracy also has multiple meanings. Specifically, I have identified four democratic traditions - aggregative, deliberative, the minimization of domination; and governance - and argued that all are apparent in popular political discourse, with actors drawing upon each to legitimize their behaviour and criticize their opponents.

There are several lessons that we can draw from this discussion. In relation to the old "insider-outsider" debates this analysis further challenges characterization of democracy as imposed. Rather than being inherently foreign, the term features on both sides of that debate. The emphasis on the multiple and contested meanings of democracy also offers lessons for donors and other would be reformers of democracy in the Pacific. Rather than appealing to a fixed standard, this discussion highlights the extent to which different meanings of democracy privilege certain types of intervention. Moreover, by highlighting the contest between these traditions it illustrates that while there is some overlap - the emphasis on executive stability in the governance tradition and the fixation with forming political parties in the aggregative tradition, for example - not all good things come together. Indeed, rather than determining whether democracy is the right regime for the Pacific, this article emphasizes that much of the debate has revolved around which type of democracy is the most legitimate. In this sense, while the Pacific debate has a unique history, it also reflects general theoretical concerns. 
The final lesson then stems from the anti-naturalist approach to concept formation that I have employed. Global interest in democracy outside Anglo-European countries has closely followed development studies. Debates have focused on whether democracy is a precondition or an outcome of development. Unlike indices that measure and rank democracy against a set of fixed criteria, this article has shown that the meaning of democracy is not fixed, it diverges both between and across countries but also time. But, despite this diversity, board patterns are apparent. None of these four traditions are likely to disappear entirely, and global norms continue to shape the regional discussion. Rather, than fixed variables, democracy features heavily in the stories we tell about what the role of government is and should be. While the practices may differ according to context - i.e. Western or NonWestern, in keeping with the theme of this special issue - at this level of abstraction perpetual concerns about suitability and transferability give way to more general questions about the legitimate basis for this type of regime.

Jack Corbett is a Research Fellow at the Centre for Governance and Public Policy, Griffith University, Brisbane, Australia. He is the author of Being Political: Leadership and Democracy in the Pacific Islands (Honolulu: University of Hawaii Press, 2015).

\section{References}

Allen, Matthew, and Sinclair Dinnen. 2010. "The North Down Under: Antinomies of Conflict and Intervention in Solomon Islands." Conflict, Security \& Development 10(3): 299327.

Baker, Kerryn. 2014. "Explaining the Outcome of Gender Quota Campaigns in Samoa and Papua New Guinea." Political Science 66(1): 63-83. 
Bertram, Geoff, and Ray F. Watters. 1985. "The MIRAB Economy in South Pacific Microstates." Pacific Viewpoint 26(3): 497-519.

Bevir, Mark and Asaf Kedar. 2008. "Concept Formation in Political Science: An Antinaturalist Critique of Qualitative Methodology." Perspectives on Politics 6(3): 503517.

Callick, Rowan. 1993. "A Doomsday Scenario" Pp. 1-11 in Pacific 2010: Challenging the Future ed. Rodeny Cole. Canberra: National Centre for Development Studies, Australian National University.

Carothers, Thomas and Diane De Gramont. 2013. Development Aid Confronts Politics: The Almost Revolution. Washington D.C.: Carnegie Endowment for International Peace.

Connell, John. 2013. Islands at Risk? Environments, Economies and Contemporary Change. Cheltenham: Edward Elgar Publishing.

Corbett, Jack. 2015. Being Political: Leadership and Democracy in the Pacific Islands. Honolulu: University of Hawaii Press.

Corbett, Jack. 2013a. "Between Crisis and Persistence. Interpreting Democracy Narratives in the Pacific Islands." Political Science 65(2): 198-215.

Corbett, Jack. 2013b. "'A Calling From God': Politicians and Religiosity in the Pacific Islands." Global Change, Peace \& Security 25(3): 283-297.

Crocombe, Ron. 1976. The Pacific Way: An Emerging Identity, Suva: Lotu Pasifika Productions.

Crocombe, Ron. 2008. The South Pacific. Suva: IPS Publications, University of the South Pacific.

Dahl, Robert Alan, and Edward R. Tufte. 1973. Size and Democracy. Stanford: Stanford University Press. 
Fraenkel, Jon. 2010. "Oceania's Political Institutions and Transitions." State Society and Governance in Melanesia Discussion Paper no 5. Canberra: ANU College of Asia and the Pacific.

Fraenkel, Jon, Stewart Firth, and Brij V. Lal. eds. 2009. The 2006 Military Takeover in Fiji: A Coup to End all Coups? Canberra: ANU E-Press.

Fraenkel, Jon. 2004a. "Electoral Engineering in Papua New Guinea: Lessons from Fiji and Elsewhere." Pacific Economic Bulletin 19(1): 122-133.

Fraenkel, Jon. 2004b. The Manipulation of Custom: From Uprising to Intervention in the Solomon Islands. Wellington: Victoria University Press.

Fraenkel, Jon. 2005. "Democracy and its Discontents" Pp. 263-270 in Securing a Peaceful Pacific, eds. John Henderson and Greg Watson. Christchurch: Canterbury University Press.

Fraenkel, Jon, Anthony Regan, and David Hegarty. 2008. "The Dangers of Political Party Strengthening Legislation in Solomon Islands." Comparative Politics 43(3): 333-361.

Field, Michael. 2010. Swimming With Sharks: Tales from the Pacific Frontline. New Zealand: Penguin Group.

Fry, Greg. 1997. "Framing the Islands: Knowledge and Power in Changing Australian Images of 'The South Pacific'." The Contemporary Pacific 9(2): 305-344.

Fry, Greg, and Tarcisius Tara Kabutaulaka, eds. 2008. Intervention and State-Building in the Pacific: The Legitimacy of 'Cooperative Intervention'. Manchester: Manchester University Press.

Halapua, Sitiveni. 2000. "Talanoa Process: The Case of Fiji." East West Centre: Hawaii. Halapua, Sitiveni. 2013. “Talanoa in Building Democracy and Governance” A paper presented for the Conference of "Future Leaders of the Pacific" Pago Pago, American Samoa, February 4-7. 
Haley, Nicole. 2008. "Strengthening Civil Society to Build Demand for Better Governance in the Pacific: Literature Review and Analysis of Good Practice and Lessons Learned." State Society and Governance in Melanesia Discussion Paper, no. 7. Canberra: ANU College of Asia and the Pacific.

Hameiri, Shahar. 2009. "The Region Within: RAMSI, The Pacific Plan and New Modes of Governance in the Southwest Pacific." Australian Journal of International Affairs 63(3): 348-360.

Hanlon, David. 2014. Making Micronesia” A Political Biography of Tosiwo Nakayama Honolulu: University of Hawaii Press.

Hau'ofa, Epeli. 1993. “Our Sea of Islands.” Pp 2-16 in A New Oceania: Rediscovering Our Sea of Island, eds. V Naidu, E Waddell \& E Hau'ofa,. Suva: School of Social and Economic Development, University of the South Pacific.

Huntington, Samuel. 1968. Political Order in Changing Societies. New Haven: Yale University Press.

Lal, Brij V. 1999. A Time to Change: The Fiji General Elections of 1999. Canberra: Department of Political and Social Change, Research School of Pacific and Asian Studies, Australian National University.

Lal, Brij V. 1998. Another Way: The Politics of Constitutional Reform in Post-Coup Fiji. Canberra: Asia Pacific Press.

Larmour, Peter. 2005. Foreign Flowers: Institutional Transfer and Good Governance in the Pacific Islands. Honolulu: University of Hawaii Press.

Larmour, Peter. 2005. Interpreting Corruption: Culture and Politics in the Pacific Islands. Honolulu: University of Hawaii Press.

Laws, Edward. 2012. "Political Settlements, Elite Pacts, and Governments of National Unity. A Conceptual Study." DLP Background Paper 10. 
Lawson, Stephanie. 1996. Tradition Versus Democracy in the South Pacific: Fiji, Tonga and Western Samoa. Cambridge: Cambridge University Press.

Lawson, Stephanie. 2010. “The Pacific Way” as Postcolonial Discourse.” The Journal of Pacific History 45(3): 297-314.

Lawson, Stephanie. 2013. "'Melanesia' The History and Politics of an Idea." The Journal of Pacific History 48(1): 1-22.

Leftwich, Adrian. 2010. "Beyond Institutions: Rethinking the Role of Leaders, Elites and Coalitions in the Institutional Formation of Developmental States and Strategies." Forum for Development Studies. 37(1): 93-111.

Levine, Stephen I., ed. 2009. Pacific Ways: Government and Politics in the Pacific Islands. Wellington: Victoria University Press.

Lijphart, Arend. 1999. Patterns of Democracy: Government Forms and Performance in Thirty-Six Countries. New Haven: Yale University Press.

Lipset, Seymour Martin. 1959. "Some Social Requisites of Democracy: Economic Development and Political Legitimacy." American Political Science Review 53(1): 69-105.

May, Ron, Wheen Katherine, and Nicole Haley. eds. 2011. Election 2007: The Shift to Preferential Voting in Papua New Guinea. Port Moresby and Canberra: The National Research Institute and the State, Society and Government in Melanesia Program. Meller, Norman, and James Anthony.1968. Fiji Goes to the Polls. The Crucial Legislative Council Elections of 1963. Honolulu: East-West Center Press.

Meller, Norman. 1969. The Congress of Micronesia: Development of the Legislative Process in the Trust Territory of the Pacific Islands. Honolulu: University of Hawaii Press.

Migdal, Joel S. 1988. Strong Societies and Weak States: State-Society Relations and State Capabilities in the Third World. Princeton: Princeton University Press. 
Moala, Kalafi. 2002. Island Kingdom Strikes Back: The Story Of An Independent Island Newspaper - Taimi O Tonga. Auckland: Paccmedia Publishers Ltd.

Morgan, Michael. 2003. "Politik is Poison: Local Conceptions of Politics in Northern Vanuatu." The New Pacific Review 2(1): 227-45.

Narokobi, Bernard. 1983. Life and Leadership in Melanesia. Suva: Institute of Pacific Studies, University of the South Pacific.

Norris, Pippa. 2012. Making Democratic Governance Work: How Regimes Shape Prosperity, Welfare, and Peace. Cambridge: Cambridge University Press.

Panapa, Paulson, and Jon Fraenkel. 2008. "The Loneliness of the Pro-government Backbencher and the Precariousness of Simple Majority Rule Tuvalu." State, Society and Governance in Melanesia Discussion Paper no. 2. Canberra: ANU College of Asia and the Pacific.

Paeniu, Lisepa. 2012. "How Can Parliamentary Democracy Function More Effectively in Small Pacific Island Countries Such as Tuvalu and Nauru?’ Journal of South Pacific Law 14(2): 6-19

Ravuvu, Asesela. 1991. The Facade of Democracy: Fijian Struggles for Political Control, 1830-1987. Suva: Reader Publishing House.

Reilly, Ben. 2001. Democracy in Divided Societies: Electoral Engineering for Conflict Management. Cambridge: Cambridge University Press.

Reilly, Ben. 2006. "Political Reform in Papua New Guinea: Testing the Evidence." Pacific Economic Bulletin 21(1): 187-194.

Reilly, Ben. 2008. "Ethnic Conflict in Papua New Guinea." Asia Pacific Viewpoint 49(1): 1222.

Rich, Roland, Hambly, Luke and Michael G. Morgan, eds. 2008. Political Parties in the Pacific Islands. Canberra: ANU E- Press. 
Richards, Jeffrey. 1982. "Politics in Small Independent Communities: Conflict or Consensus?" The Journal of Commonwealth \& Comparative Politics 20(2): 155-171. Sahlins, Marshall D. 1963. "Poor Man, Rich Man, Big Man, Chief: Political Types in Melanesia and Polynesia." Comparative Studies in Society and History 5(3): 285-303. Schattschneider, Elmer Eric. 1942. Party Government. New York: Rinehart.

Schmitt, Carl. 2007. The Concept of the Political. Chicago: University of Chicago Press. Shapiro, Ian. 2003. The State of Democratic Theory. Princeton: Princeton University Press. Standish, Bill. 2006. "Limited Preferential Voting in Papua New Guinea: Some Early Lessons." Pacific Economic Bulletin 21(1): 195-211.

Steeves, Jeffery S. 1996. "Unbounded Politics in the Solomon Islands: Leadership and Party Alignments." Pacific Studies 19(1): 115-138.

Teaiwa, Teresia. 2005. "Ethnicity and Identity." pp. 271-274 in Securing a Peaceful Pacific eds. John Henderson and Greg Watson. Christchurch: Canterbury University Press. Underwood, Robert. 2006. "Micronesian Political Structures and American Models: Lessons Taught and Lessons Learned." The Journal of Pacific Studies 29(1): 4-24.

Van Fossen, Anthony. 2005. South Pacific Futures: Oceania Toward 2050. Foundation for Development Cooperation.

Van Trease, Howard, ed. 1993. Atoll politics: the Republic of Kiribati. Christchurch and Suva: Macmillan Brown Centre for Pacific Studies, The University of Canterbury and IPS, University of the South Pacific.

Van Trease, Howard, ed. 1995. Melanesian Politics: Stael Blong Vanuatu. Christchurch and Suva: Macmillan Brown Centre for Pacific Studies, The University of Canterbury and IPS, University of the South Pacific.

Veenendaal, Wouter P., and Jack Corbett. 2015. "Why Small States Offer Important Answers to Large Questions." Comparative Political Studies 48(4): 527-549. 
Walton, Grant. 2013. "Is All Corruption Dysfunctional? Perceptions of Corruption and its Consequences in Papua New Guinea" Public Administration and Development 33(3): 175-190.

Weber, Max. 1978. "Politics as a Vocation". Pp. 212-225 in Max Weber: Selections in Translation ed. W.G. Runciman. Cambridge: Cambridge: Cambridge University Press. 